\title{
Baja peninsula claims five victims in tragic accident
}

\section{San Diego}

The ecological research community is in shock following the death of five of its members. The researchers were on an expedition in the Gulf of California, off Mexico's Baja peninsula, when their boat was caught in a sudden wind storm.

Among the dead are Gary Polis, chairman of the department of environmental science and policy at the University of California at Davis, and three Japanese researchers from Kyoto University: Takuya Abe, Masahiko Higashi and Shigeru Nakano, who is presumed dead although his body had not been recovered by last weekend. Michael Reese, a postgraduate ecologist at Davis, also drowned.

Four other members of the team - three graduate students and a postgraduate were rescued after swimming for nearly four hours to islands.

Polis, a zoologist known for his research on scorpions, was also president of the American Society of Naturalists. Abe and Nakano were known for their work on biodiversity in the tropical forests of

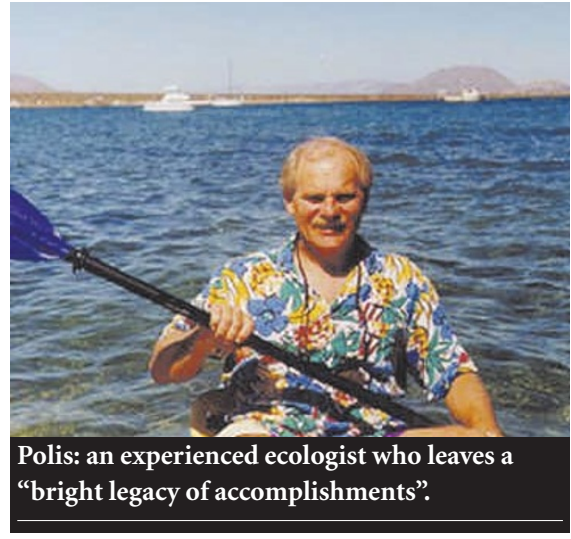

Borneo; Higashi was a specialist in foodweb theory.

"The researchers who died left us a bright legacy of accomplishments that will make them remembered," says Richard Atkinson, president of the University of California.

The Baja peninsula, which stretches for 950 sparsely populated kilometres down Mexico's northwest coast, is home to a wide range of plants and animals. But its desolate beauty masks many dangers, such as the sudden winds that can sweep off Baja's mountainous desert at up to $80 \mathrm{~km}$ per hour, whipping the water into huge waves.

The research team was operating about $500 \mathrm{~km}$ south of San Diego, near the remote fishing village of Bahia del Los Angeles on Baja's eastern shore, an area Polis knew well. They left the village in the morning in two motorized boats to do fieldwork on the Isla de Cabeza de Caballo, about 6 km offshore.

The open boats were returning to the village at midday when disaster struck. The boats became separated in the high seas, and one was swamped.

The researchers' project - examining spiders and scorpions - is funded by the US National Science Foundation and the Earthwatch Institute.

The Japanese researchers were building links between Kyoto and Davis, both specifically related to the project and more generally. They arrived in Davis the previous week and had spent a few days at the university before driving south into Mexico. Rex Dalton \& David Cyranoski

\section{Reshuffle lifts French synchrotron hopes}

Paris

The sacking of France's research minister, Claude Allègre, a fortnight ago has cast uncertainty over the level of France's promised participation in the construction of the British synchrotron Diamond - and has reawakened hopes that a French machine might also be built.

Government officials in Paris say that

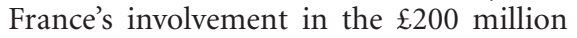
(US\$313 million) Diamond, which is being jointly financed by the British government and the Wellcome Trust, has not been sealed by any formal agreement. The controversial decision to participate was taken by Allègre last year, ending eight years of plans to build a French machine, Soleil (see Nature 400, 489; 1999).

France's new science minister, RogerGérard Schwartzenberg, has not made any official statement about Soleil. But he has promised to study the dossier, together with a recent parliamentary report urging the science ministry to push ahead with the construction of Soleil "without further delay" (see Nature 404, 323; 2000).

Allègre had argued that Soleil would be too expensive to build and that large scientific equipment should be built at the European level. But his decision, which was strongly criticized by France's scientific and political communities, was not sealed by any formal agreement between the two governments and the Wellcome Trust, according to Vincent Courtillot, research director under Allègre.

In principle, Schwartzenberg could reduce France's financial investment in Diamond so as to proceed with the French project - France is unlikely to be able to afford the FF350 million (US\$51 million) announced by Allègre for Diamond as well as pay for a new synchrotron on its own soil.

Another option would be for France to find other partners for Soleil. Belgium, Holland and Spain are possible candidates, says Courtillot, who is expected to remain on Schwartzenberg's team.

Senator René Trégouët (RPR, Rhône), an author of the parliamentary report, said last week that France should remain flexible over Diamond so as to have access to some beamlines on the machine, while also being able to move ahead with a French synchrotron.

Trégouët says French researchers will need at least ten beamlines over the next decade, and that the most economic solution would be to rent beamlines on Diamond and build a national machine with a foreign partner.

"The decision [to build] Soleil should be taken very rapidly. We need to construct a machine in France and we need to have an accord, perhaps between England, Germany and France," says Trégouët.

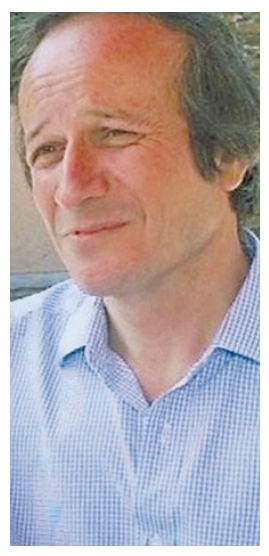

Schwartzenberg: a reprieve for Soleil?
Schwartzenberg, a professor of law at the University of Paris and a seasoned politician, is relatively unknown to the scientific community, and would gain an immediate political boost by resurrecting Soleil.

"We hope with this new minister that we will have [our own synchrotron] source," says Bernard Capelle, director of research at the Centre National de la Recherche Scientifique and a member of the tripartite group planning Diamond with the Wellcome Trust and the British government.

"It probably will not be a completely French source, and we might have to reduce our participation in Diamond. But the two machines would be complementary, with the French machine having a lower energy," Capelle says.

A spokesperson for Britain's Central Laboratory for the Research Councils, which will run Diamond, declined to comment. The issue was believed due to be discussed with French officials this week. Heather McCabe 